\title{
VALIDITY OF MIDDLE UPPER ARM CIRCUMFERENCE AS AN INDICATOR OF NUTRITIONAL STATUS IN PATIENTS WITH CANCER UNDERGOING CHEMOTHERAPY
}

\author{
Marynda Rahmadianisya'), Chodidjah²), Minidian Fasitasari3) \\ 1)Faculty of Medicine, Universitas Islam Sultan Agung \\ 2)Department of Anatomy, Faculty of Medicine, Universitas Islam Sultan Agung \\ 3)Department of Nutrition, Faculty of Medicine, Universitas Islam Sultan Agung/ \\ Sultan Agung Islamic Hospital, Semarang
}

\begin{abstract}
Background: Middle Upper Arm Circumference (MUAC) is the circumference of the left upper arm, measured at the middle point between the tip of the shoulder and the tip of the elbow (olecranon process and the acromium). MUAC is used for the assessment of nutritional status. It is a good predictor of mortality and in many studies, MUAC predicted death in children better than any other anthropometric indicator. This study aimed to validity of middle upper arm circumference as an indicator of nutritional status in patients with cancer undergoing chemotherapy.

Subjects and Method: A cross-sectional study was conducted at Sultan Agung Islamic hospital, Semarang, Central Java. A sample of 52 cancer patients undergoing chemotherapy was selected for this study. The independent variable was body mass index (BMI) served as the gold standard. The dependent variable was middle upper arm circumference (MUAC). Both indicators were measured by anthropometric measurement. Sensitivity and specificity were calculated to indicate validity. BMI and MUAC scores were analyzed by Pearson correlation.

Results: MUAC had a strong and positive correlation with BMI ( $\mathrm{r}=0.76$; $\mathrm{p}<0.001)$. In comparison with BMI, MUAC showed high sensitivity (94.7\%) and moderate specificity (75.8\%).

Conclusion: MUAC is strongly correlated with BMI with high sensitivity and moderate specificity. It can be used as an indicator of nutritional status in cancer patients undergoing chemotherapy.
\end{abstract}

Keywords: middle upper arm circumference, body mass index, nutritional status, cancer

\section{Correspondence:}

Minidian Fasitasari. Faculty of Medicine, Universitas Islam Sultan Agung, Jl. Raya Kaligawe KM 4, Semarang, Central Java. Email: minidian@unissula.ac.id.

Mobile: (024) 6583584. Fax: (o24) 6594366

The 4th International Conference on Public Health

Best Western Premier Hotel, Solo, Indonesia, August 29-30, 2018 | 48

https://doi.org/10.26911/theicph.2018.01.09 